\title{
Shell dimension-weight relationships in the blood cockle Larkinia grandis (Bivalvia: Arcidae) on the southeastern coast of the Gulf of California
}

\section{Relaciones entre la dimensión y el peso de la concha en el berberecho Larkinia grandis (Bivalvia: Arcidae) en la costa sureste del golfo de California}

\author{
Maria Isabel Sotelo-Gonzalez ${ }^{1}$, Carlos Humberto Sepúlveda ${ }^{1}$, Rebeca Sánchez-Cárdenas ${ }^{2}$, Luis \\ Antonio Salcido-Guevara ${ }^{2}$, Manuel García-Ulloa ${ }^{3 *}$, Andrés Martín Góngora-Gómez ${ }^{3}$, Juan Antonio \\ Hernández-Sepúlveda ${ }^{3}$ \\ ${ }^{1}$ Facultad de Ciencias del Mar, Universidad Autónoma de Sinaloa. Avenida de los Deportes, s/n, Ciudad \\ Universitaria, CP 82017, Mazatlán, Sinaloa, Mexico. \\ ${ }^{2}$ Facultad de Ciencias del Mar, Universidad Autónoma de Sinaloa. Paseo Claussen, s/n, Colonia Los Pinos, CP \\ 82000, Mazatlán, Sinaloa, Mexico. \\ ${ }^{3}$ Instituto Politécnico Nacional, Centro Interdisciplinario de Investigación para el Desarrollo Integral Regional, \\ Unidad Sinaloa. Blvd. Juan de Dios Bátiz Paredes, no. 250, Colonia San Joachin, CP 81101, Guasave, \\ Sinaloa, Mexico. \\ * Corresponding author. E-mail: turbotuag@hotmail.com
}

\begin{abstract}
The blood cockle Larkinia grandis is a commercially important resource in the Gulf of California, but little information is available on this species. In this study, the interactions between body weight (BW) and shell length (SL), height (SH), and width (SW) were evaluated in a L. grandis population in the Gulf of California, Mexico. Eighty cockles were hand-picked monthly from August 2017 to July 2018 near and/or under mangrove trees on the southeastern coast of the Gulf of California. The range of shell measurements $(\mathrm{SL}=142.00-44.57 \mathrm{~mm}$, $\mathrm{SH}=85.50-31.15 \mathrm{~mm}, \mathrm{SW}=76.56-32.03 \mathrm{~mm}$ ) indicates that the sampled population was dominated by adult specimens. Only the coefficient of variation for BW exhibited high dispersion $(23 \%-45 \%)$. The potential relationships between BW and SL, SH, and SW were non-linear. The strongest interaction was found between BW and SW $\left(R^{2}=0.934\right)$, with the BW-SW relationship best describing the growth of this ark clam. All shell dimension-weight relationships were significant $(P \leq 0.05)$, indicating both negative (SL-SW and SH-SW) and positive (SL-SH, $\mathrm{BW}-\mathrm{SL}, \mathrm{BW}-\mathrm{SH}$, and BW-SW) allometric growth. The $b$ values ranged from 0.8950 , for the LogSH-LogSW relationship, to 2.6240 , for the LogBW-LogSH interaction. This preliminary information is useful for developing conservation and sustainable exploitation strategies for this species, which is of economic importance to this region.
\end{abstract}

Key words: morphometry, mangrove cockle, allometric growth, coefficient of variation, Gulf of California.

RESUMEN. El berberecho Larkinia grandis es un recurso comercialmente importante en el golfo de California, pero hay poca información disponible acerca de esta especie. En este estudio, se evaluaron las interacciones entre el peso corporal (BW) y la longitud (SL), la altura (SH) y el ancho (SW) de la concha en una población de L. grandis en el golfo de California, México. Se recolectaron a mano 80 berberechos mensualmente, desde agosto de 2017 hasta julio de 2018, de cerca y/o debajo de los árboles de mangle, en la costa sureste del golfo de California. El intervalo de medidas de las conchas ( $\mathrm{SL}=142.00-44.57 \mathrm{~mm}, \mathrm{SH}=85.50-31.15 \mathrm{~mm}, \mathrm{SW}=76.56-32.03 \mathrm{~mm}$ ) indica que la población muestreada estaba dominada por especímenes adultos. Solo el coeficiente de variación para BW exhibió alta dispersión (23\%-45\%). Las relaciones potenciales de BW con SL, SH y SW no fueron lineales. La interacción más fuerte se encontró entre BW y SW $\left(R^{2}=0.934\right)$; la relación BWSW describió mejor el crecimiento de este árcido. Todas las relaciones entre la dimensión y el peso de la concha fueron significativas $(P \leq 0.05)$, lo cual indica tanto crecimiento alométrico negativo (SL-SW y SH-SW) como positivo (SL-SH, BW-SL, BW-SH y BW-SW). Los valores de $b$ oscilaron entre 0.8950 , para la relación LogSH-LogSW, y 2.6240, para la interacción LogBW-LogSH. Esta información preliminar es útil para desarrollar estrategias de conservación y explotación sostenible para esta especie de importancia económica en la región estudiada.

Palabras clave: morfometría, berberecho de manglar, crecimiento alométrico, coeficiente de variación, golfo de California.

\section{INTRODUCTION}

The blood cockle Larkinia grandis (= Anadara grandis) (Broderip and Sowerby 1829) is a bivalve of commercial importance with distribution from Laguna Ballena in Baja California, Mexico, to Tumbes in northern Peru (Coan and Valentich-Scott 2012). Along with other ark clam species in the Arcidae family, L. grandis is extracted as part of the

\section{INTRODUCCIÓN}

El berberecho Larkinia grandis (= Anadara grandis) (Broderip y Sowerby 1829) es un bivalvo de importancia comercial que se distribuye desde la laguna Ballena en Baja California, México, hasta Tumbes en el norte de Peru (Coan y Valentich-Scott 2012). Al igual que otros árcidos de la familia Arcidae, L. grandis es extraída por la pesquería de 
blood clam or "pata de mula" fishery along the Pacific coast of Mexico. The annual catch records for this species are made on the basis of reports by local fishermen to the authorities, with reported numbers frequently being lower than the actual extracted volume. Also, the catch record for this ark clam in official documents is not species-specific (CONAPESCA 2018), and there is currently no fishing ban to protect this bivalve (CONAPESCA 2017).

The relationships between shell dimensions and body weight are a useful tool for accurately interpreting the development and relative growth of bivalves. Previous research on L. grandis has provided information on age and growth (Cruz 1986), size and sexual maturity (Cruz 1987), and reproduction in the wild (Borda and Cruz 2004) and in cultures (Reynoso-Granados et al. 2012). However, most of this information has been documented for populations outside the Gulf of California. To our knowledge, morphometric studies of other Arcidae clams on the Pacific coast are scarce. Thus, the objective of this study was to evaluate the morphometric relationships (shell dimensions-weight) in a L. grandis population from the southeastern Gulf of California over the course of one year. The interaction between body weight and shell length is expected to better describe clam growth. This information is important for assessing growth and morphometric relationships in L. grandis and developing economically (fishery and aquaculture) and ecologically sustainable management plans for this species.

\section{MATERIALS AND METHODS}

Specimen collection was carried out monthly from August 2017 to July 2018 in El Cohui estuary $\left(25^{\circ} 26^{\prime}-19^{\circ} 38^{\prime} \mathrm{N}\right.$, $105^{\circ} 48^{\prime}-43^{\circ} 90^{\prime} \mathrm{W}$ ), Guasave municipality (Sinaloa, Mexico), in the central Gulf of California. The specimens ( $n=80$ every month) were hand-picked in the intertidal zone of the mangrove area and placed in a plastic container $(50 \mathrm{~L})$ with seawater for transportation to the laboratory. A Vernier caliper $(0.01 \mathrm{~mm})$ was used to measure shell length $(\mathrm{SL})$ or maximum distance between the anterior and posterior margins, shell height ( $\mathrm{SH}$ ) or maximum distance from the umbo to the ventral margin, and shell width (SW) or maximum distance between the thickest parts of the 2 valves. Body weight (BW) was measured using a digital scale with $0.01 \mathrm{~g}$ accuracy.

Atypical values were cleaned from all datasets (DurbinWatson's test) and residuals were analyzed for normal distribution by the quantile-quantile plot (RStudio, R Core Team 2018). The relationships between the different shell dimensions and BW $(n=960)$ were estimated using the potential regression $\mathrm{W}=a \mathrm{~L}^{b} e$, where $\mathrm{W}$ is $\mathrm{BW}(\mathrm{g})$; $\mathrm{L}$ is $\mathrm{SL}, \mathrm{SH}$, or SW (mm); $a$ is the intercept; $b$ is the slope; and $e$ is the typical error. In relations with different measurement units, when $b=3$, BW-shell measurement relationships indicate isometric growth. The goodness of fit was analyzed using the Pearson correlation coefficient $(r)$ (Sokal and Rohlf 1981). The coefficient of variation (CV) was calculated for pata de mula a lo largo de la costa mexicana del Pacífico. El registro de la captura anual de esta especie se basa en las capturas reportadas por los pescadores locales ante las autoridades, las cuales frecuentemente son menores que el volumen realmente extraído. Además, el registro de captura para este árcido no es específico para la especie (CONAPESCA 2018) y, actualmente, no hay veda que proteja a este bivalvo (CONAPESCA 2017).

Las relaciones entre las dimensiones de la concha y el peso corporal son una herramienta útil para interpretar con precisión el desarrollo y el crecimiento relativo de los bivalvos. Investigaciones anteriores sobre $L$. grandis han proporcionado información sobre la edad y el crecimiento (Cruz 1986), el tamaño y la madurez sexual (Cruz 1987) y la reproducción en la naturaleza (Borda y Cruz 2004) y en cultivos (Reynoso-Granados et al. 2012). Sin embargo, la mayor parte de esta información ha sido documentada para poblaciones fuera del golfo de California. Hasta donde sabemos, los estudios morfométricos de otras almejas Arcidae en la costa del Pacífico son escasos. Por lo tanto, el objetivo de este estudio fue evaluar las relaciones morfométricas (dimensiones de la concha con relación al peso) en una población de L. grandis del sureste del golfo de California en el transcurso de un año. Se espera que la interacción entre el peso corporal y la longitud de la concha describa mejor el crecimiento de las almejas. Esta información es importante para evaluar el crecimiento y las relaciones morfométricas en L. grandis y desarrollar planes de manejo para esta especie que sean sostenibles económicamente (pesca y acuicultura) y ecológicamente.

\section{MATERIALES Y MÉTODOS}

Los especímenes se recolectaron mensualmente desde agosto de 2017 hasta julio de 2018 en el estero El Cohui $\left(25^{\circ} 26^{\prime}-19^{\circ} 38^{\prime} \mathrm{N}, 105^{\circ} 48^{\prime}-43^{\circ} 90^{\prime} \mathrm{W}\right)$, en el municipio de Guasave (Sinaloa, México), en la parte central del golfo de California. Las muestras ( $n=80$ cada mes) se recolectaron a mano en la zona intermareal del manglar y se colocaron en un recipiente de plástico $(50 \mathrm{~L})$ con agua de mar para ser transportadas al laboratorio. Se utilizó una regla Vernier $(0.01 \mathrm{~mm})$ para medir la longitud de la concha (SL) o la distancia máxima entre los márgenes anterior y posterior, la altura de la concha $(\mathrm{SH})$ o la distancia máxima desde el umbo hasta el margen ventral, y el ancho de la concha (SW) o la distancia máxima entre las partes más gruesas de las 2 valvas. Se utilizó una balanza digital con precisión de $0.01 \mathrm{~g}$ para medir el peso corporal (BW).

Los valores atípicos se eliminaron de todos los conjuntos de datos (prueba de Durbin-Watson) y los residuos se analizaron para determinar la distribución normal mediante el gráfico de cuantil-cuantil (RStudio, R Core Team 2018). Las relaciones entre las diferentes dimensiones de la concha y el BW $(n=960)$ se estimaron utilizando la regresión potencial $\mathrm{W}=a \mathrm{~L}^{b} e$, donde $\mathrm{W}$ es el $\mathrm{BW}(\mathrm{g})$; L es SL, SH o SW (mm); 
all shell measurements as well as for BW. The estimation of the morphometric relationships between the variables was performed by adjusting the linear function of the data (least square method) using the formula $\log Y=\log a+b \log X+$ $e$ (Ricker 1973), where $\log Y$ and $\log X$ are the logarithm of SL and SH or BW and the logarithm of SH, SL, and SW, respectively; $a$ is the intercept (initial growth coefficient); $b$ is the slope (relative growth range of the variables); and $e \approx \mathrm{N}\left(0, \sigma^{2}\right)$ is a normal variate. The correction factor, $\mathrm{CF}=$ $e^{\frac{S_{Y \mid X}^{2}}{2}}$, was used for the log-transformed values in order to avoid underestimations of mean values on the original scale. The degree of association between the variables was obtained with the coefficient of determination $\left(R^{2}\right)$. The confidence limits of $b$ and the level of correlation $(r)$ also were estimated. To identify significant differences in the isometric value of $b(b=1)$ or the allometric range (negative allometry $b<1$, or positive allometry $b>1$ ) obtained in the linear regression, a Student's $t$-test was applied (Ho: $b=1$ ), with a 95\% confidence level, using the following equation: $t=$ $(b-1) / \mathrm{S} b$, where $t$ is the $t$-test value, $b$ is the slope, and $\mathrm{S} b$ is the standard error of the slope (Vasconcelos et al. 2018). Regression analysis was used to determine the morphometric data for the SL-SH, SL-SW, SH-SW, BW-SL, BW-SH, and BW-SW relationships (log-transformed).

\section{RESULTS}

The shell dimensions considered in this analysis $(n=$ 960) ranged from 44.57 to $142.00 \mathrm{~mm}$ for SL, from 31.15 to $85.50 \mathrm{~mm}$ for $\mathrm{SH}$, and from 32.03 to $76.56 \mathrm{~mm}$ for SW, whereas BW varied from 41.90 to $337.00 \mathrm{~g}$ (Table 1). The CV values obtained for SL, SH, and SW were below $20 \%$; however, the CV value for BW exhibited high dispersion (23\%$45 \%$ ). The relationships between BW and SL, SH, and SW were nonlinear (Fig. 1). All coefficients of determination $\left(R^{2}\right)$ between BW and the different shell dimensions exceeded 0.87 and indicated negative allometric growth. The $a$ and $b$ values for the BW-SL and BW-SH relationships were 0.0084 and 2.27 , and 0.0038 and 2.61, respectively. The strongest interaction was found between $\mathrm{BW}$ and $\mathrm{SW}\left(R^{2}=0.934\right)$ and was expressed as $\mathrm{BW}=0.0049 \mathrm{SW}^{2.61}(12.36)$. The relationships between shell measurements showed $r$ values between 0.88 (for SL-SW) and 0.95 (for BW-SH and BW-SW) (Table 2). Student's $t$-tests revealed significant differences $(P \leq 0.05)$ in all L. grandis shell dimension-weight relationships, representing both negative (SL-SW and $\mathrm{SH}-\mathrm{SW}$ ) and positive (SL-SH, BW-SL, BW-SH, and BW-SW) allometric growth. The $b$ values ranged from 0.8950 (for the LogSHLogSW relationship) to 2.6240 (for the $\operatorname{LogBW}-\operatorname{LogSH}$ interaction).

\section{Discussion}

The blood cockle is a natural resource of economic importance on coasts along the Gulf of California, Mexico, $a$ es la intersección; $b$ es la pendiente; y e es el error típico. En las relaciones con diferentes unidades de medida, cuando $b=$ 3 , las relaciones del $\mathrm{BW}$ con la medida de la concha indican un crecimiento isométrico. La bondad del ajuste se analizó mediante el coeficiente de correlación de Pearson ( $r$ ) (Sokal y Rohlf 1981). El coeficiente de variación (CV) se calculó para todas las medidas de la concha y para el BW. La estimación de las relaciones morfométricas entre las variables se realizó ajustando la función lineal de los datos (método de cuadrados mínimos) mediante la fórmula $\log \mathrm{Y}=\operatorname{Loga}+b \log \mathrm{X}+e$ (Ricker 1973), donde LogY y LogX son el logaritmo de SL y SH o BW y el logaritmo de SH, SL y SW, respectivamente; $a$ es la intersección (coeficiente de crecimiento inicial); $b$ es la pendiente (rango de crecimiento relativo de las variables); y $e \approx \mathrm{N}\left(0, \sigma_{1}^{2}\right)$ es una variante normal. El factor de corrección, $\mathrm{FC}=e^{\frac{S_{Y \mid X}^{2}}{2}}$, se utilizó para los valores transformados logarítmicamente con el fin de evitar subestimaciones de los valores promedio en la escala original. El grado de asociación entre las variables se obtuvo con el coeficiente de determinación $\left(R^{2}\right)$. También se estimaron los límites de confianza de $b$ y el nivel de correlación $(r)$. Para identificar diferencias significativas en el valor isométrico de $b(b=1)$ o el rango alométrico (alometría negativa $b<1$, alometría positiva $b>$ 1) obtenido en la regresión lineal, se aplicó una prueba $t$ de Student (Ho: $b=1$ ), con un nivel de confianza del $95 \%$, utilizando la siguiente ecuación: $t=(b-1) / \mathrm{S} b$, donde $t$ es el valor de la prueba $t, b$ es la pendiente y $S b$ es el error estándar de la pendiente (Vasconcelos et al. 2018). Se utilizó el análisis de regresión para determinar los datos morfométricos de las relaciones SL-SH, SL-SW, SH-SW, BW-SL, BW-SH y BWSW (transformado logarítmicamente).

\section{Resultados}

El intervalo de las dimensiones de las conchas que se consideraron en este análisis $(n=960)$ fue de 44.57 a $142.00 \mathrm{~mm}$ para SL, de 31.15 a $85.50 \mathrm{~mm}$ para SH y de 32.03 a $76.56 \mathrm{~mm}$ para SW, mientras que el intervalo de BW fue de 41.90 a $337.00 \mathrm{~g}$ (Tabla 1). Los valores de CV obtenidos para SL, SH y SW fueron inferiores al 20\%; sin embargo, el valor del CV para BW presentó una dispersión amplia (23\%-45\%). Las relaciones entre BW y SL, SH y SW fueron no lineales (Fig. 1). Todos los coeficientes de determinación $\left(\mathrm{R}^{2}\right)$ entre el BW y las diferentes dimensiones de la concha excedieron $0.87 \mathrm{e}$ indicaron un crecimiento alométrico negativo. Los valores $a$ y $b$ para las relaciones BW-SL y BWSH fueron 0.0084 y 2.27 , y 0.0038 y 2.61 , respectivamente. La interacción más fuerte se encontró entre BW y SW $\left(R^{2}=\right.$ $0.934)$ y se expresó como $\mathrm{BW}=0.0049 \mathrm{SW}^{2.61}(12.36)$. Las relaciones entre las medidas de la cocha mostraron valores de $r$ de entre 0.88 (para SL-SW) y 0.95 (para BW-SH y BW$\mathrm{SW}$ ) (Tabla 2). Las pruebas $t$ de Student revelaron diferencias significativas $(P \leq 0.05)$ en todas las relaciones entre las dimensiones y el peso de la concha de L. grandis, lo cual representa un crecimiento alométrico tanto negativo (SL-SW 


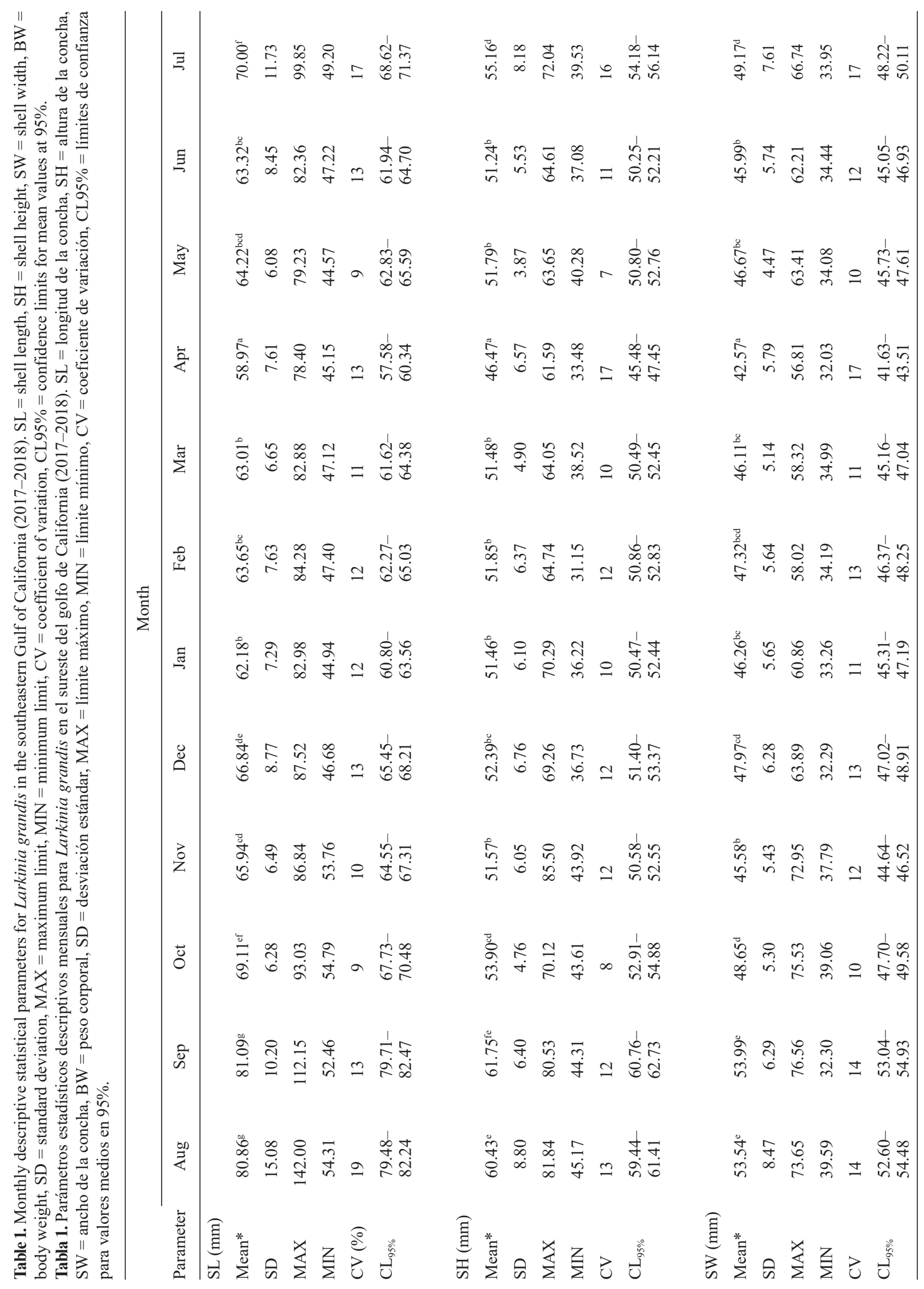




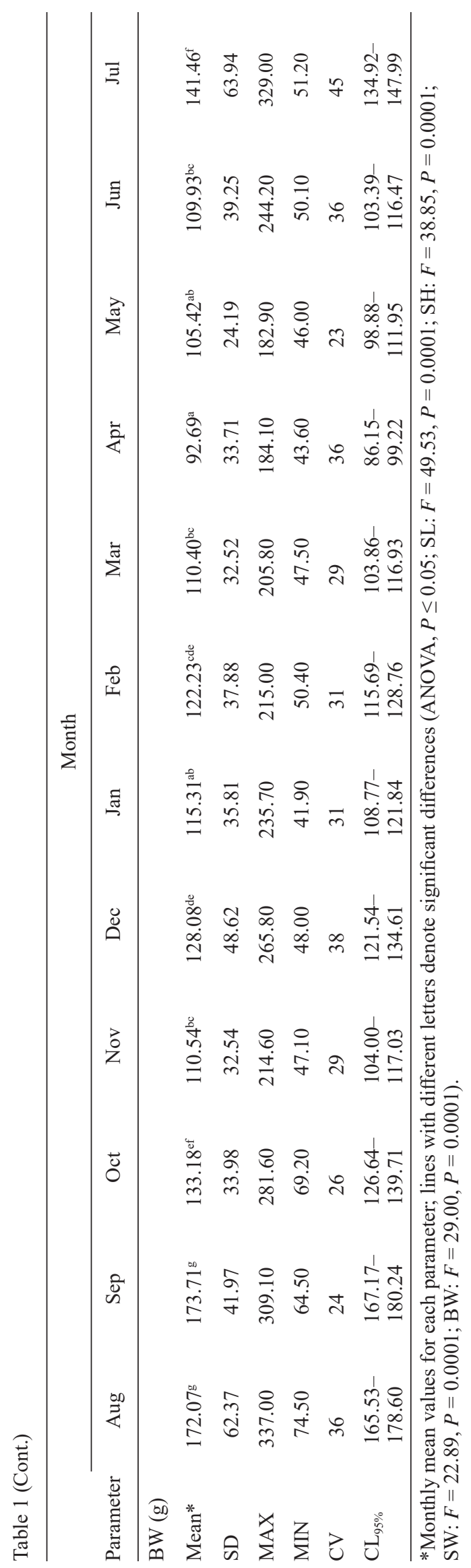


yet growth and morphometry information is lacking for this species. The maximum and minimum shell lengths of the collected blood cockle specimens (44.57-142 mm) indicate that the morphometric analysis in the present study was performed on adult clams of reproductive age. For a wild population in Costa Rica, Cruz (1987) concluded that specimens of $A$. grandis measuring 21-24 mm total length (TL) were sexually mature adults. This coincides with Borda and Cruz (2004) reporting reproductive adulthood in A. tuberculosa at $25 \mathrm{~mm}$ TL. The CV for BW showed high dispersion (24\%$45 \%$ ), suggesting a possible reproductive event during sampling (Khalil et al. 2017). The shell measurement ranges, the 2 peaks observed for $\mathrm{BW}$, and consequently the higher $\mathrm{CV}$ obtained for BW suggest the gonad maturation index as the main cause of the BW fluctuation (Menoud et al. 2016).

The regression equations for the relationships between BW and the 3 shell measurements indicate negative allometric growth in $L$. grandis, with values of $b<3$. This means the BW increase is not proportional to the cube of SL. Gaspar et al. (2001) indicated that the negative allometric growth of bivalves is associated with adult specimens that remain mostly buried in sediment, where the shells are not exposed to waves, which was the case for the L. grandis population in this study. The slope of the BW-SL interaction (2.3021) for the entire L. grandis sample population was lower (2.356) than that reported by Cruz (1986) for the same species and lower $(b=$ 3.188) compared with Anadara demiri in the Adriatic Sea, Italy (Morello et al. 2004). Since the present study spanned all 4 seasons, it is likely that the $b$ values obtained for the interactions between BW and shell dimensions are strongly linked to the $L$. grandis reproductive strategy.

The correlation coefficient $(r)$ of the log-transformed interactions ranged from 0.88 (SL-SW) to 0.95 (BW-SW and $\mathrm{BW}-\mathrm{SH}$ ), suggesting that $\mathrm{BW}-\mathrm{SW}$ and $\mathrm{BW}-\mathrm{SH}$ are the most appropriate morphometric relationships for describing the growth of L. grandis individuals from El Cohui, Sinaloa, directly in the field with the equations $\operatorname{LogBW}=-2.2905+$ $2.6046 \log \mathrm{SW}+0.0218$ and $\operatorname{LogBW}=-2.4479+2.6240 \mathrm{Log}$ $\mathrm{SH}+0.0188$, without using a scale. Typically, the shape of an Arcidae cockle shell is elongated or squared (Meshram and Mohite 2016), and this is mainly determined by SL (maximum antero-posterior distance) and SW (maximum distance between the outermost edges of the 2 valves).

Our results represent essential preliminary information on the morphometry of L. grandis in El Cohui, Sinaloa, Mexico. We found that (1) the collected blood cockle population sample was dominated by adults; (2) the BW values suggest the occurrence of reproductive events during the sampling year; (3) the interaction between $\mathrm{BW}$ and shell dimensions showed a nonlinear pattern; (4) all interactions between $L$. grandis measurements showed values of $b<$ 1 for linear relationships and $<3$ for weight relationships, indicating negative allometric growth; and (5) BW-SW was the most solid relationship for describing this species' relative growth. Also, this study is the first to provide essential y SH-SW) como positivo (SL-SH, BW-SL, BW-SH y BWSW). El intervalo de los valores de $b$ fue de 0.8950 (para la relación $\operatorname{LogSH}-\mathrm{LogSW}$ ) a 2.6240 (para la interacción $\log \mathrm{B} W-\operatorname{LogSH})$.

\section{Discusión}

El berberecho es un recurso natural de importancia económica a lo largo de la costa del golfo de California, México, pero existe poca información acerca del crecimiento y la morfometría de esta especie. Las longitudes máximas y mínimas (44.57-142.00 mm) de las conchas de los berberechos recolectados indican que, en el presente estudio, el análisis morfométrico se realizó en almejas adultas de edad reproductiva. Para una población silvestre en Costa Rica,
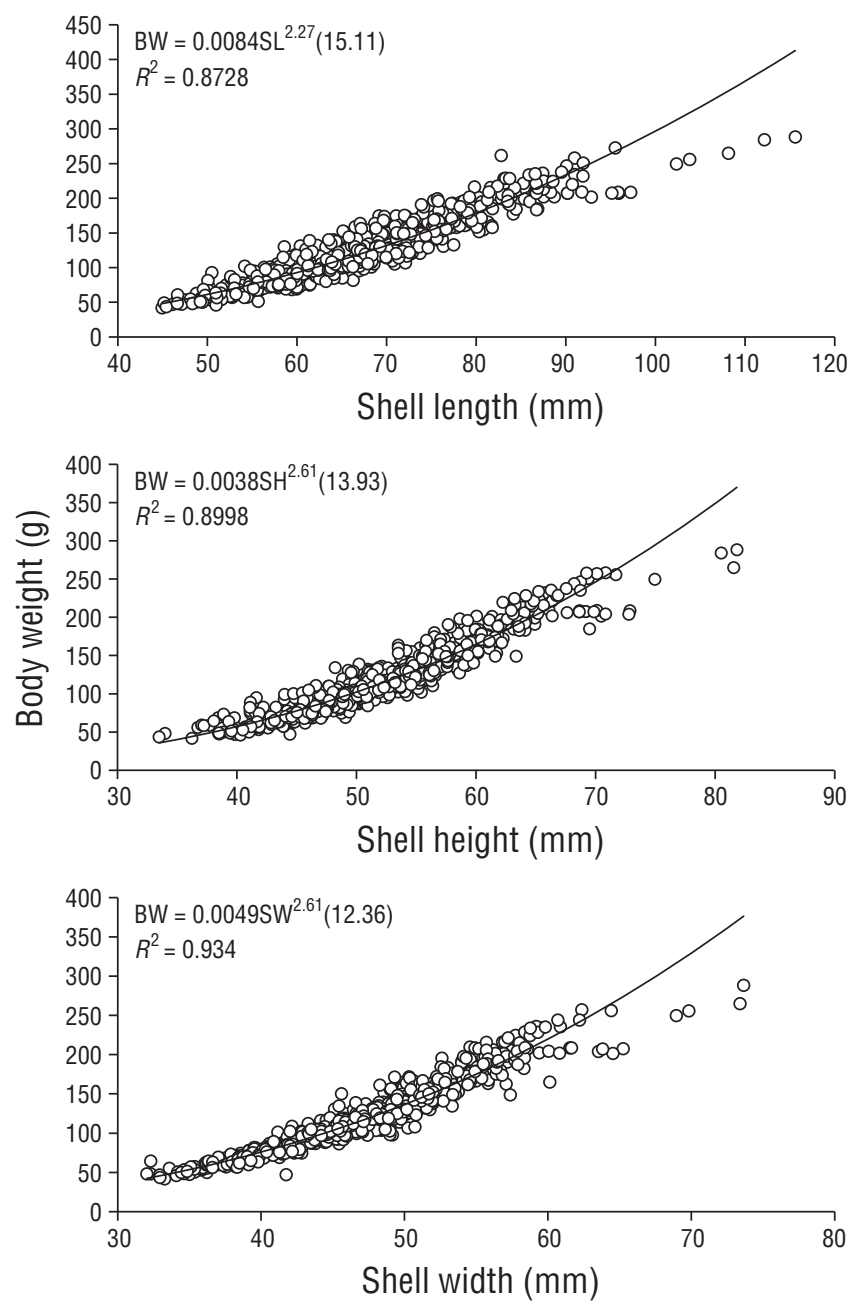

Figure 1. Morphometric relationship between body weight and shell dimensions (length, width, and height) for the blood cockle Larkinia grandis.

Figura 1. Relación morfométrica entre el peso corporal y las dimensiones de la concha (largo, ancho y alto) del berberecho Larkinia grandis. 
Table 2. Morphometric relationships (mm, log-transformed) and type of growth for Larkinia grandis in the southeastern Gulf of California (2017-2018).

Tabla 2. Relaciones morfométricas ( $\mathrm{mm}$, transformación logarítmica) y tipo de crecimiento de Larkinia grandis en el sureste del golfo de California (2017-2018).

\begin{tabular}{|c|c|c|c|c|}
\hline Equation & $r$ & $\begin{array}{c}b \pm \mathrm{SE} \\
(\mathrm{CI} 95 \%)\end{array}$ & $t$-test & Type of growth \\
\hline $\operatorname{LogSL}=-0.0120+1.0658 \operatorname{LogSH}+0.0280$ & 0.93 & $\begin{array}{r}1.0658 \pm 0.0132 \\
(1.0400-1.0916)\end{array}$ & $-4.98^{*}$ & +Allometric \\
\hline $\operatorname{LogSL}=0.1696+0.9871 \operatorname{LogSW}+0.0258$ & 0.88 & $\begin{array}{l}0.9871 \pm 0.0168 \\
(0.9542-1.0200)\end{array}$ & $0.77^{*}$ & -Allometric \\
\hline $\operatorname{LogSH}=0.2229+0.8950 \operatorname{LogSW}+0.0280$ & 0.90 & $\begin{array}{l}0.8950 \pm 0.0140 \\
(0.8676-0.9224)\end{array}$ & $7.50^{*}$ & -Allometric \\
\hline $\operatorname{LogBW}=-2.1264+2.3021 \operatorname{LogSL}+0.0182$ & 0.94 & $\begin{array}{l}2.3021 \pm 0.0269 \\
(2.2494-2.3548)\end{array}$ & $-48.40 *$ & +Allometric \\
\hline $\operatorname{LogBW}=-2.4479+2.6240 \operatorname{LogSH}+0.0188$ & 0.95 & $\begin{array}{l}2.6240 \pm 0.0295 \\
(2.5662-2.6818)\end{array}$ & $-55.05^{*}$ & +Allometric \\
\hline $\operatorname{LogBW}=-2.2905+2.6046 \operatorname{LogSW}+0.0218$ & 0.95 & $\begin{array}{l}2.6046 \pm 0.0281 \\
(2.5495-2.6597)\end{array}$ & $-57.10^{*}$ & +Allometric \\
\hline
\end{tabular}

$r=$ correlation coefficient, $b=$ slope, $\mathrm{SE}=$ standard error of $b, \mathrm{CI}=95 \%$ confidence interval, $\mathrm{SL}=$ shell length, $\mathrm{SH}=$ shell height, $\mathrm{SW}=$ shell width, $\mathrm{BW}=$ body weight. Asterisk denotes a significant difference $(P \leq 0.05)$.

morphometric data that confirms the current status of this blood cockle population and contributes to the development of strategies for the conservation and/or sustainable exploitation (fishery and aquaculture) of this economically important ark clam species on the southeastern coast of the Gulf of California.

\section{ACKNOWLedgments}

We thank the Instituto Politécnico Nacional for the logistical and economic support provided for the development of this research through the projects IPNSIP 20200527 and IPNSIP 20200526. MISG is grateful for the scholarship awarded by the National Council for Science and Technology (Mexico, 714818) to carry out her doctoral studies. The Sinaloa IPN-CIIDIR's Ethics Committee approved this research. We thank Dr. Kristin Sullivan for editing the English text.

\section{REFERENCES}

Borda CA, Cruz R. 2004. Reproducción y reclutamiento del molusco Anadara tuberculosa (Sowerby, 1833) en el Pacífico colombiano. Rev Invest Mar. 25(3):185-195.

Coan EV, Valentich-Scott P. 2012. Bivalve seashells of tropical west America. Marine bivalve mollusks from Baja California to Peru. Santa Barbara, (CA): Santa Barbara Museum of Natural History. 1257 p.

[CONAPESCA] Comisión Nacional de Acuacultura y Pesca (MX). 2017. Anuario Estadístico de Acuacultura y Pesca 2017 de la Comisión Nacional de Acuacultura y Pesca. Mazatlán (Sinaloa, Mexico): CONAPESCA(MX); [accessed 2020Feb 01].
Cruz (1987) concluyó que los especímenes de A. grandis que medían entre 21 y $24 \mathrm{~mm}$ de longitud total (LT) eran adultos sexualmente maduros. Esto coincide con lo reportado por Borda y Cruz (2004), que indicaron que la edad adulta reproductiva en Anadara tuberculosa se presenta a los $25 \mathrm{~mm}$ LT. El CV para BW mostró una alta dispersión (24\%-45\%), lo que sugiere que posiblemente ocurrió un evento reproductivo durante el muestreo (Khalil et al. 2017). Los intervalos de las medidas de las conchas, los 2 picos observados para el BW y el consecuente mayor CV obtenido para el BW sugieren que el índice de maduración de las gónadas es la principal causa de la fluctuación del BW (Menoud et al. 2016).

Las ecuaciones de regresión para las relaciones entre el BW y las 3 medidas de la concha indican un crecimiento alométrico negativo en L. grandis, con valores de $b<3$. Esto significa que el aumento del BW no es proporcional al cubo de SL. Gaspar et al. (2001) indicaron que el crecimiento alométrico negativo de bivalvos se relaciona con ejemplares adultos que permanecen mayoritariamente enterrados en el sedimento, donde las conchas no están expuestas al oleaje, como ocurrió en la población de L. grandis en este estudio. La pendiente de la interacción BW-SL (2.3021) para toda la población de muestra de L. grandis fue menor (2.356) que la reportada por Cruz (1986) para la misma especie y menor $(b=3.188)$ en comparación con Anadara demiri en el mar Adriático, Italia (Morello et al. 2004). Dado que el presente estudio abarcó las 4 estaciones, es probable que los valores de $b$ obtenidos para las interacciones entre el BW y las dimensiones de la concha estén fuertemente vinculados a la estrategia reproductiva de L. grandis. 
Www.conapesca.gob.mx/work/sites/cona/dgppe/2017/ ANUARIO_ESTADISTICO_2017.pdf

[CONAPESCA] Comisión Nacional de Acuacultura y Pesca (MX). 2018. Anuario Estadístico de Acuacultura y Pesca 2018 de la Comisión Nacional de Acuacultura y Pesca. Mazatlán (Sinaloa, Mexico): CONAPESCA (MX). 253 p.

Cruz RA. 1986. Caracteres generales, edad y crecimiento de Anadara grandis (Pelecypoda: Arcidae). Uniciencia. 3(1):25-29.

Cruz RA. 1987. Tamaño y madurez sexual en Anadara grandis (Pelecypoda: Arcidae). Brenesia. 27:9-12.

Gaspar MB, Santos MN, Vasconcelos P. 2001. Weight-length relationships of 25 bivalve species (Mollusca: Bivalvia) from the Algarve coast (southern Portugal). J Mar Biol Assoc UK. 81(5):805-807. https://doi.org/10.1017/S0025315401004623

Khalil M, Yasin Z, Hwai TS. 2017. Reproductive biology of blood cockle Anadara granosa (Bivalvia: Arcidae) in the northern region of the Strait of Malacca. Ocean Sci J. 52(1):75-89. https://doi.org/10.1007/s12601-017-0010-y

Menoud M, Van Wynsberge S, Le Moullac G, Levy P, Andréfouët S, Remoissenet G, Gaertner-Mazouni N. 2016. Identifying robust proxies of gonad maturation for the protandrous hermaphrodite Tridacna maxima (Röding, 1798, Bivalvia) from individual to population scale. J Shellfish Res. 35(1):51-61. https://doi.org/10.2983/035.035.0107

Meshram AM, Mohite SA. 2016. Morphometric study of blood clam, Tegillarca rhombea (Born, 1778). J Fish Livestock Prod. 4(3):179. https://doi.org/10.4172/2332-2608.1000179

Morello EB, Solustri C, Froglia C. 2004. The alien bivalve Anadara demiri (Arcidae): a new invader of the Adriatic Sea, Italy. J Mar Biol Assoc UK. 84(5):1057-1064. https://doi.org/10.1017/S0025315404010410h

R Core Team. 2018. R: A language and environment for statistical computing: R Foundation for Statistical Computing. Vienna (Austria): The R Foundation; accessed 2020 Jan 28. https:// www.R-project.org/.

Reynoso-Granados T, Monsalvo-Spencer P, Saucedo PE, MazónSuástegui JM, Robles-Mungaray M. 2012. Settlement and early nursery of juvenile Anadara grandis (Pelecypoda: Arcidae) under different conditions at the hatchery and ponds. J Shellfish Res. 31(3):769-775. https://doi.org/10.2983/035.031.0321

Ricker WE. 1973. Linear regressions in fishery research. J Fish Res Board Can. 30(3):409-434. https://doi.org/10.1139/f73-072

Sokal RR, Rohlf FJ. 1981. Biometry. New York (NY): WH Freeman. $859 \mathrm{p}$.

Vasconcelos P, Moura P, Pereira F, Pereira AM, Gaspar MB. 2018. Morphometric relationships and relative growth of 20 uncommon bivalve species from the Algarve coast (southern Portugal). J Mar Biol Assoc UK. 98(3):463-474. https://doi.org/10.1017/S002531541600165X

Received April 2020, accepted July 2020.
El coeficiente de correlación $(r)$ de las interacciones transformadas logarítmicamente estuvo entre 0.88 (SL$\mathrm{SW}$ ) y 0.95 (BW-SW y BW-SH), lo que sugiere que las relaciones morfométricas $\mathrm{BW}-\mathrm{SW}$ y $\mathrm{BW}-\mathrm{SH}$ son las más apropiadas para describir el crecimiento de los individuos de L. grandis de El Cohui, Sinaloa, directamente en el campo con las ecuaciones $\operatorname{LogBW}=-2.2905+2.6046 \log \mathrm{SW}+$ 0.0218 y $\operatorname{LogBW}=-2.4479+2.6240 \log \mathrm{SH}+0.0188, \mathrm{sin}$ usar una balanza. Por lo general, la forma de la concha de un berberecho Arcidae es alargada o cuadrada (Meshram y Mohite 2016), y esto está determinado principalmente por la SL (distancia anteroposterior máxima) y SW (distancia máxima entre los bordes más externos de las 2 válvulas).

Nuestros resultados constituyen información preliminar esencial sobre la morfometría de L. grandis en El Cohui, Sinaloa, México. Encontramos que (1) la muestra recolectada de la población de berberechos estaba dominada por adultos; (2) los valores de BW sugieren que ocurrieron eventos reproductivos durante el año de muestreo; (3) la interacción entre $\mathrm{BW}$ y las dimensiones de la concha mostró un patrón no lineal; (4) todas las interacciones entre las mediciones de L. grandis mostraron valores de $b<1$ para las relaciones lineales y $<3$ para las relaciones de peso, lo que indica un crecimiento alométrico negativo; y (5) la relación BW-SW fue la más sólida para describir el crecimiento relativo de esta especie. Asimismo, este estudio es el primero en brindar datos morfométricos esenciales que confirman el estado actual de esta población de berberechos y contribuye al desarrollo de estrategias para la conservación y/o explotación sustentable (pesca y acuicultura) de esta especie de almeja arca de importancia económica en la costa sureste del golfo de California.

\section{Agradecimientos}

Agradecemos al Instituto Politécnico Nacional por el apoyo logístico y económico brindado para el desarrollo de esta investigación a través de los proyectos IPNSIP 20200527 e IPNSIP 20200526. MISG agradece la beca otorgada por el Consejo Nacional de Ciencia y Tecnología (México, 714818) para llevar a cabo sus estudios de doctorado. El Comité de Ética del IPN-CIIDIR Sinaloa aprobó esta investigación. Agradecemos a la Dra. Kristin Sullivan por editar el texto en inglés.

Traducido al español por Claudia Michel-Villalobos. 